will be amply rewarded by the discovery of many new forms, whatever group he may choose to take in hand. Mr. P. Marshall recently described sixty-six species in a first instalment of New Zealand diptera, fifty-four of which were new (Trans. N.Z. Inst., vol. xxviii.).

As the general laws regarding the distribution of species can only be discovered from the knowledge of a very great number of facts, I fully agree with the Rev. T. Blackburn that "the special task to be accomplished by this generation, and in the present state of knowledge, is that of collecting and recording facts and data" (Presidential Address, Trans. Roy. Soc. South Australia, I891, vol. xiv. p. 371); and that when we attempt to generalise we find how very little is known in comparison to what is yet to be discovered, and feel "the need of that exhaustive collection of the data and records of the facts that we are at present engaged in procuring." Nevertheless, I cannot concur in the suggestion that we should altogether relegate "the investigation of the reasons of the facts of nature" to the naturalists of the next generation. Not only is it even now exceedingly interesting and important to summarise what we do know and to understand the direction in which our observations are tending, but it also makes all future work immensely more interesting, and enables the work to be carried out more intelligently and thoroughly. It is, however, very necessary when recording facts to have the mind free from all theories and preconceived ideas which might in any way influence one's observations and conclusions.

Wellington, N.Z.

\section{The Resistance of the Air.}

REFERRING to Mr. Bryan's summary, on page 107 of the current volume of NATURE, of the observations on the resistance of the air, made by Le Dantec and by Canovetti, it is but fair to say that the conclusion "No. 3," viz. that the resistance to a plane surface depends upon its contour, i.e. whether circular, square or triangular, is by no means new. Precisely this result was deduced by Prof. Hagen, of Berlin, in his most delicate experiments published by the Berlin Academy in 1874. His memoir is the first in Abbe's collection of translations, entitled "The Mechanics of the Earth's Atmosphere," and a detailed discussion of his results is given at pp. $234-238$ of his " Treatise on Meteorological Apparatus and Methods." Hagen's results, when expressed in grams, decimetres and seconds, give the resistance per square decimetre as $(0.00707+0.0001125 p) v^{2}$ where $p$ is the contour of the plate and $v$ the velocity. As his experiments were made with plates of only from $\mathrm{I}$ to $\mathrm{I} 2 \mathrm{deci}$ metres on a side, and as he showed that the size affects the coefficient quite as much as the shape, it would scarcely be proper to exterpolate from his small plates up to the large ones used by the French investigators. We should not expect any close agreement for a surface of one metre square between Hagen's figures and these newer ones, but the general law that the pressure per square unit depends upon both the size and the shape of the plate is due to Hagen. The explanation of this result is also largely due to him; it is not merely a question of gaseous viscosity or internal friction, but especially of that dissipation of energy that occurs in the ideal perfect fluid, and which has been called convective friction in the above-mentioned treatise and elsewhere. Le Dantec and Canovetti, by experimenting on a large scale, have necessarily encountered such irregularities and difficulties as must have limited the accuracy of their results quite as much as in the case of many other experiments since those of Sir Isaac Newton. In general, inasmuch as resistance per square unit varies with the size and shape of plane plates or other bodies, it can hardly be called an important physical constant of great scientific interest. It certainly has a practical interest to the aeronaut, the navigator, and the millwright, but the scientific interest of such experiments consist essentially in determining the lines of flow and the transformations of energy involved in the discontinuous motions.

Washington, December 13, 1899

C. A.

THE object of my notice was to give a general account of Le Dantec's and Canovetti's experiments, and certainly not to deliver judgment on those delicate questions of priority which are mainly of personal interest. The "law of perimeters" being so noticeably put forward as a new result, I could do no less than cite the views of Le Dantec and his referee, between whom and Hagen or his advocate "C. A." the matter must rest. There is surely a contradiction of terms in your correspondent's expression, " that dissipation of energy that occurs in the ideal perfect fluid, and which has been called convective friction in the above-mentioned treatise and elsewhere." A fluid which dissipates energy, especially by means of anything called friction, is not an "ideal perfect fluid" according to universally accepted definitions. As to the "scientific interest " of determinations, not only of the aërial resistance of a square metre, but also of the weight of a cubic centimetre of water, the so-called mechanical equivalent of heat, the electrical resistance of a copper wire, the E.M.F. of a Clark cell, or any other physical quantity whose value is affected by various conditions, this surely is a matter of opinion; but the great amount of attention which is now devoted to accumulating statistical data of this class is sufficient indication of a general consensus of opinion in favour of such researches being regarded as valuable from a scientific standpoint.

G. H. BRYAN.

\section{Grey's Rock Paintings.}

IN Prof. Haddon's review of Mr. Mathews' “Eaglehawk and Crow" there are several references to Grey's rock paintings, amongst which your reviewer remarks, "These rock paintings are certainly very puzzling, and deserve renewed investigation on the spot." They were investigated by Mr. A. C. Gregory, the Australian explorer, who, about seventeen years ago, gave me the following particulars relating to them :-

"The importance of the native coloured drawings, published by Grey in his " Travels," is much exaggerated. The colours are by no means so bright as printed, and the drawings are generally of a very primitive kind, more or less crude outlines of hands or weapons placed on the face of rocks, and lines marked round the edge of the object" (see Jour. Anth. Inst., xvi., p. I33). I have also a clear remembrance of Mr. Gregory blaming the printers for attempting to make comparatively finished drawings of the faces out of crude outlines much in the same way as was so commonly done in the elaborate plates that accompany the volumes of Cook's "Voyages." Mr. Mathews' "identification" may therefore be dismissed.

Halifax, Yorks., January 1.

H. LING ROTH.

\section{Evidence of Upheaval in Vanua Levu, Fiji.}

DURING an examination of the geology of this large island evidence of very extensive upheaval frequently came under my observation. Speaking generally, the main elevated mass of the island is the product of submarine fissure-eruptions. Its surface is in great part traversed by mountainous ridges, which form an intricate system, and consist in each case of an axis of basic and often coarsely crystalline volcanic rocks concealed beneath calcareous tuffs and volcanic muds, which in their turn are covered over by agglomerates. During the movement of upheaval, and in the ages that have since elapsed, the denuding agencies have been so actively at work that it is not easy to restore the original form of the surface; but it may be observed that in the eighteen months of my stay no evidence of a crateral cavity came under my notice in the main mass of the island. By studying the contours it can be shown that Vanua Levu has been formed by the union during the process of upheaval of a number of smaller islands with a central larger island.

Foraminiferous and pteropod-bearing muds together with calcareous volcanic tuffs are not infrequènt up to elevations of I 100 or 1200 feet. They are of scanty occurrence at greater heights; but they are to be found in different parts of the island at elevations of from 1500 to 2000 feet; and in one locality I found sea-shells in a coarse tuff at 2200 feet. Elevated coralreefs have taken a very little part in the building-up of the island. They exist in a few localities at the coast, and do not attain a higher level than some 200 feet. In this connection it should be noted that flints and silicified corals occur on the surface of the lower regions all over the island. Corals in various stages of silicification are found in quantities in some places, especially where a low-lying district now marks the situation of what was once an inland sea.

R. C. Mission, Rewa, Fiji, November 21, I899.

NO. I 576 , VOL. 61] 